\title{
Relative importance of early-successional forests and shrubland habitats to mammals in the northeastern United States
}

\author{
Todd K. Fuller ${ }^{\mathrm{a}, *}$, Stephen DeStefano ${ }^{\mathrm{b}}$ \\ ${ }^{a}$ Department of Natural Resources Conservation, University of Massachusetts, 160 Holdsworth Way, Amherst, MA 01003, USA \\ ${ }^{\mathrm{b}}$ USGS, Massachusetts Cooperative Fish and Wildlife Research Unit, University of Massachusetts, \\ 160 Holdsworth Way, Amherst, MA 01003, USA
}

\begin{abstract}
The majority of the 60 native terrestrial mammal species that reside in the northeastern United States (US) utilize resources from several habitats on a seasonal basis. However, as many as 20 species demonstrate some preference for early-successional forests, shrublands, or old-field habitats. A few of these (e.g. lagomorphs) can be considered obligate users of these habitats, and the specialist carnivores (e.g. felids) that prey on them may consequently also prefer such habitats. Other mammal species that prefer these habitats certainly depend on them to lesser and varying degrees; thus, the consequences of reducing or eliminating early-successional forests, shrublands, or old-field habitats across the landscape will likely have varying demographic consequences, and thus importance, to those species.
\end{abstract}

(C) 2003 Elsevier B.V. All rights reserved.

Keywords: Early-successional forests; Shrubland; Habitat; Mammals; Northeastern United States

\section{Introduction}

Conservation of biological diversity necessitates, by its very definition, conscientious management efforts with regard to the entire variety of naturally occurring ecosystems in any region or locale. The fact that early-successional communities in the northeastern United States (US) have largely been ignored in this context (Askins, 2001), mostly because they are perceived as uninteresting or unappealing (Gobster, 2001), makes them no less valuable and no less important a resource.

A variety of animal species can be found in earlysuccessional forests, shrublands, and old-field habitats

\footnotetext{
* Corresponding author. Tel.: +1-413-545-4723; fax: +1-413-545-4358.

E-mail address: tkfuller@forwild.umass.edu (T.K. Fuller).
}

(e.g. Hunter et al., 2001; Dettmers, 2003; Wagner et al., 2003). However, the consequences of substantially reducing the abundance of these habitats across regional landscapes will likely have varying demographic consequences because the degree to which species depend on them will certainly vary. Litvaitis (2001) identified three species of mammals as obligate users of earlysuccessional habitats in the Northeast; the eastern cottontail rabbit (Sylvilagus floridanus), the New England cottontail (S. transitionalis), and the bobcat (Lynx rufus). Populations of New England cottontails, in particular, rise and fall with land clearing and subsequent regrowth of forests, and in recent years have been eliminated from much of their range in the Northeast because of maturing forests (Litvaitis and Litvaitis, 1996).

Litvaitis (2001) also identified examples of facultative or opportunistic users of early-successional 
habitats in the Northeast; these included the black bear (Ursus americanus), the little brown bat (Myotis lucifugus), and the white-tailed deer (Odocoileus virginianus). However, no one has made a complete assessment of the mammal species occurring in the Northeast with respect to their relative dependence on early-successional habitats. This is an important exercise because the efforts to restore or maintain such habitats may have more consequences than previously known. Thus, we set out to identify the relative importance of early-successional habitats to all mammal species in the Northeast via a review of existing literature.

To assess the dependence of individual species of mammals on early-successional habitats, one would ideally look for studies that experimentally compared the population responses of mammal species to differences in the abundance of such habitats. Those studies would assess major demographic changes (e.g. in density, reproduction, or survival) in response to elimination of early-successional habitat types. Not surprisingly, such studies are lacking for almost all mammal species occurring in the Northeast. As a substitute, we asked ourselves if wildlife habitat research identifying "preferred" or "selected" habitats (sensu Garshelis, 2000, p. 112; the choosing of resources, as suggested in use/availability studies) could connote demographic importance. We believed that habitat can influence demographic performance, especially if viewed in the context of habitat specialization; that is, if the relative use of some habitats was high. Therefore, our task was to identify which mammal species in the Northeast "selected" or "preferred" early-successional habitats, and then to assess in some relatively straightforward way their relative habitat preferences. We believed that a ranking of species by this relative dependence would give us insights into the potential demographic consequences attending changes in the amount and distribution of early-successional habitats in the Northeast.

\section{Methods}

\subsection{Literature source}

Fortunately for us, DeGraaf and Yamasaki (2001) conducted a recent and exhaustive review of the literature, and provide updated natural history profiles of all terrestrial and semi-aquatic vertebrate species in New England. In addition, they presented habitat associations in the form of habitat matrices for all vertebrates endemic to the region, one for forested and one for non-forested cover-types. We used these habitat matrices as the basis for our analysis of use of early-successional stage vegetative cover by mammals in the northeastern US.

\subsection{Data base}

For every species, the matrices are arranged by seasonal use (rows) and cover-type (columns). The four seasonal use categories for both matrices allows for use of habitat types as breeding season shelter, breeding season feeding, winter season shelter, and winter season feeding.

The forested matrix is comprised of 11 forest covertypes. These include aspen (Populus tremuloides and $P$. grandidentata), paper birch (Betula papyrifera), northern hardwoods (including sugar maple (Acer saccharum), beech (Fagus grandifolia), and yellow birch (Betula alleghaniensis)), red maple (Acer rubrum), balsam-fir (Abies balsamea), red spruce (Picea rubens)-fir, red spruce, eastern hemlock (Tsuga canadensis), northern red oak (Quercus rubra), pine-oak-maple (including eastern white pine (Pinus strobus)), and eastern white pine. Within each type four size-classes are listed: regeneration through seedlings $(<2.5 \mathrm{~cm}$ diameter at breast height (dbh)), sapling through pole (2.5-23 or $30 \mathrm{~cm} \mathrm{dbh}$ ), sawtimber, and large sawtimber; the northern hardwood type also included an "uneven-aged" category. Thus, within the forest matrix, there is a total of 180 season/type combinations, or cells ([10 forest types with 4 size-classes +1 with 5 size-classes $(n=45)] \times 4$ seasonal use categories $)$.

The non-forested matrix includes three general habitat categories: terrestrial, wetland/deep water, and other habitats. We identified 14 terrestrial and other nonwetland types within these categories that seemed relevant to mammal species that might use terrestrial early-successional habitats. These types include cultivated, grass, forbs, shrub/old field, pasture, savanna, orchard, krummholz, alpine, stable bank, ledge/cliff, cave/mine, structure, and derelict building/debris. Thus, within the non-forest matrix, there is a total of 56 cells (14 non-forested types $\times 4$ seasonal use categories). 
For each of the season/type combinations (cells), DeGraaf and Yamasaki (2001) provided a rating of preferred, utilized, or not utilized. These were subjective assessments of the relative importance of a covertype to an individual species based on the literature, opinions of acknowledged experts, or the authors' extensive field experience.

\subsection{Data analysis}

For the non-forest matrix, we considered only the "shrubland/old-field" type as early-successional habitat. For the forest matrix, we considered only the "regeneration through seedling" size class (which includes stems $<2.5 \mathrm{~cm} \mathrm{dbh}$ ) of each forest type as (very) early-successional habitat. We did not include the sapling through pole size class, even though sapling-sized trees $(<12.7 \mathrm{~cm} \mathrm{dbh})$ often are included in such categorizations (e.g. Trani et al., 2001). This was because DeGraaf and Yamasaki (2001) combined saplings with pole-sized stands, and these larger trees clearly are not considered to be part of early-successional habitats.

To estimate the relative importance of early-successional habitats to mammal species, we then used the matrices in the following ways. First, we identified all mammal species that had $\geq 1$ "cell" identified as preferred or utilized in the regeneration through seedling size or in the shrub/old-field type (i.e. seedling/shrub). We then calculated two proportions for each species that used these types. The first was the proportion of preferred or used seedling/shrub cells to the total number of preferred and used cells of any type; this indicated to us how important the overall use of the seedling/shrub types might be. The second was the proportion of preferred seedling/shrub cells to the total number of preferred cells only. If preferred seedling/shrub cells predominated, we might suspect that a species was an obligate user of that type. Subsequent to these calculations, we ordered both proportions for each species from highest to lowest to examine the ratios themselves, the differences between ratios for a given species, and the relative differences in ratios among species.

\section{Results}

Of the 60 native terrestrial mammal species that occur in New England (DeGraaf and Yamasaki, 2001),
$56(93 \%)$ were identified as using or preferring $\geq 1$ seedling/shrub matrix cell (out of 180 forest +56 nonforest $=236$ total cells) at some time of year. The four species with no apparent use of early-successional habitats (gray squirrel (Sciurus carolinensis), northern flying squirrel (Glaucomys sabrinus), southern flying squirrel (G. volans), and river otter (Lontra canadensis)) are either arboreal or aquatic. In addition, 36 $(64 \%)$ of the 56 species that did use seedling/shrub habitats did not have any preferred cells in those habitats. The 20 other species (36\%) had 1-44 seedling/shrub cells marked as preferred in the matrix.

The comparison of proportions for these 20 species (Table 1) indicated that the lagomorphs used earlysuccessional habitats more exclusively than any other species. For cottontails, in particular, more than half their used and preferred cells were in such habitats. For six other species, however, more than half of cells identified as preferred were in early-successional habitats.

\section{Discussion}

Our survey confirmed Litvaitis' (2001) conclusion that cottontail rabbits in the Northeast are obligates users of early-successional habitat types; both species show high overall use, and high preferred use of such types. The bobcat, a lagomorph specialist, was identified as preferring early-successional types, though it clearly uses many other cover-types and hunts for many other species throughout its range (Rolley et al., 1987). Little brown bats were not identified as preferring any early-successional habitats, but they do use all such types. In fact, nearly all mammals in the Northeast (56 of 60) use early-successional habitats, and there is evidence that 20 , or nearly one-third, have a preference, in varying degrees, for such types.

In a recent survey (DeStefano, 2002), forest wildlife biologists in North America were asked to list the species of greatest concern in their region. Of the 14 mammal species listed that occur in New England, 9 (64\%) are those that we identified as preferring, to some extent, early-successional habitats. The role of disturbance agents, such as fire, windthrow, or smallscale logging, in setting back succession and maintaining patches of habitat on the landscape was cited as a major area of interest and concern in this same survey. 
Table 1

Relative preference and use of early-successional habitats (seedling tree and shrub/old fields) by selected mammals based on habitat matrices in DeGraaf and Yamasaki (2001)

\begin{tabular}{|c|c|c|c|c|c|c|}
\hline \multirow[t]{2}{*}{ Species $^{\mathrm{a}}$} & \multicolumn{3}{|c|}{$\begin{array}{l}\text { No. of preferred and used } \\
\text { cells combined }\end{array}$} & \multicolumn{3}{|c|}{ No. of preferred cells only } \\
\hline & $\begin{array}{l}\text { Seedling and } \\
\text { shrub/old field }\end{array}$ & $\begin{array}{l}\text { All } \\
\text { types }\end{array}$ & Proportion & $\begin{array}{l}\text { Seedling and } \\
\text { shrub/old field }\end{array}$ & $\begin{array}{l}\text { All } \\
\text { types }\end{array}$ & Proportion \\
\hline Eastern cottontail (Sylvilagus floridanus) & 36 & 42 & 0.86 & 10 & 20 & 0.50 \\
\hline New England cottontail (Sylvilagus transitionalis) & 32 & 55 & 0.58 & 12 & 12 & 1.00 \\
\hline Snowshoe hare (Lepus americanus) & 44 & 132 & 0.33 & 35 & 37 & 0.95 \\
\hline Indiana myotis (Myotis sodalis) & 12 & 42 & 0.29 & 1 & 4 & 0.25 \\
\hline Lynx (Lynx canadensis) & 27 & 96 & 0.28 & 18 & 20 & 0.90 \\
\hline Moose (Alces alces) & 27 & 103 & 0.26 & 14 & 19 & 0.74 \\
\hline Beaver (Castor canadensis) & 32 & 132 & 0.24 & 6 & 24 & 0.25 \\
\hline Deer mouse (Peromyscus maniculatus) & 48 & 200 & 0.24 & 20 & 88 & 0.23 \\
\hline Southern red-backed vole (Clethrionomys gapperi) & 48 & 204 & 0.24 & 28 & 56 & 0.50 \\
\hline Red fox (Vulpes vulpes) & 48 & 201 & 0.24 & 44 & 49 & 0.90 \\
\hline Mink (Mustela vison) & 44 & 182 & 0.24 & 4 & 16 & 0.25 \\
\hline Striped skunk (Mephitis mephitis) & 39 & 167 & 0.23 & 1 & 4 & 0.25 \\
\hline Ermine (Mustela erminea) & 48 & 206 & 0.23 & 4 & 4 & 1.00 \\
\hline White-footed mouse (Peromyscus leucopus) & 48 & 216 & 0.22 & 16 & 60 & 0.27 \\
\hline White-tailed deer (Odocoileus virginianus) & 25 & 128 & 0.20 & 6 & 20 & 0.30 \\
\hline Black bear (Ursus americana) & 23 & 122 & 0.19 & 10 & 21 & 0.48 \\
\hline Opossum (Didelphis virginia) & 15 & 87 & 0.17 & 2 & 14 & 0.14 \\
\hline Bobcat (Lynx rufus) & 25 & 155 & 0.16 & 4 & 8 & 0.50 \\
\hline Raccoon (Procyon lotor) & 13 & 106 & 0.12 & 2 & 13 & 0.15 \\
\hline Porcupine (Erethizon dorsatum) & 13 & 124 & 0.10 & 4 & 33 & 0.12 \\
\hline
\end{tabular}

Data represent the frequency of the number of early-successional habitat matrix cells (maximum =48) that are "preferred" and "used" by a species relative to all "preferred" and "used" forested and terrestrial non-forested habitat type cells (maximum =236). Proportions identified in bold indicate $\geq 50 \%$ of the cells were in early-successional habitats.

${ }^{\text {a }}$ These 20 mammal species (of the 60 native mammal species in New England) each were identified in DeGraaf and Yamasaki (2001) as having $\geq 1$ "preferred" early-successional habitat matrix cell.

Thus, concern over this particular habitat type and many of the mammals in it is noteworthy. Still, it is apparent that the public needs to be convinced that early-successional habitats are interesting, and are in fact a key component of the landscape in the northeastern United States. Once this is done, there are a variety of options for managing early-successional forests and shrublands (DeGraaf and Yamasaki, 2003).

\section{Conclusions}

It seems clear that the relative importance of earlysuccessional habitats to mammals likely depends on the degree of specialization of the species (e.g. lagomorphs and bobcats). Although some species may not be true early-successional habitat "obligates" (e.g. bobcats), they may still show important demographic responses to elimination of such habitat, and thus their prey (e.g. Litvaitis et al., 1986). Finally, a good number of less-considered species may have important early-successional habitat needs. For very few mammal species do we have definitive demographic data showing responses to changes in the abundance of early-successional habitats, but with proper planning (e.g. Garshelis, 2000) we may be able to make a more convincing argument concerning such changes.

One must also remember that the interpretation of our results depends on several things. First, the analyses do not include sapling (3-9 cm dbh) habitats, and do include old fields. And second, the matrices are an artificial construct to help us understand habitat relationships, but are not definitive- "the only thing worse than not having the matrices compiled is completely believing them" (DeGraaf, personal communication). 


\section{Acknowledgements}

We thank John Litvaitis for inviting us to prepare this paper and Richard DeGraaf for providing useful comments on the draft manuscript.

\section{References}

Askins, R.A., 2001. Sustaining biological diversity in earlysuccessional communities: the challenge of managing unpopular habitats. Wildl. Soc. Bull. 29, 407-412.

DeGraaf, R.M., Yamasaki, M., 2001. New England Wildlife: Habitat, Natural History, and Distribution. University Press of New England, Hanover, New Hampshire.

DeGraaf, R.M., Yamasaki, M., 2003. Options for managing early successional forests and shrubland bird habitats in the northeastern United States. For. Ecol. Manage. 185, 179-191.

DeStefano, S., 2002. Regional and national issues for forest wildlife research and management. For. Sci. 48, 1-9.

Dettmers, R., 2003. Status and conservation of shrubland birds in the northeastern United States. For. Ecol. Manage. 185, 81-93.

Garshelis, D.L., 2000. Delusions in habitat evaluation: measuring use, selection, and importance. In: Boitani, L., Fuller, T.K. (Eds.), Research Techniques in Animal Ecology: Controversies and Consequences. Columbia University Press, New York, pp. 111-164.

Gobster, P.H., 2001. Human dimensions of early-successional landscapes in the eastern United States. Wildl. Soc. Bull. 29, 474-482.

Hunter, W.C., Buehler, D.A., Canterbury, R.A., Confer, J.L., Hamel, P.B., 2001. Conservation of disturbance-dependent birds in eastern North America. Wildl. Soc. Bull. 29, 440-455.

Litvaitis, J.A., 2001. Importance of early-successional habitats to mammals in eastern forests. Wildl. Soc. Bull. 29, 466-473.

Litvaitis, M.K., Litvaitis, J.A., 1996. Using mitochondrial DNA to inventory the distribution of remnant populations of New England cottontails. Wildl. Soc. Bull. 24, 727-730.

Litvaitis, J.A., Sherburne, J.A., Bissonette, J.A., 1986. Bobcat habitat use and home range size in relation to prey density. J. Wildl. Manage. 50, 110-117.

Rolley, R.E., 1987. Bobcat. In: Novak, M., Baker, J.A., Obbard, M.E., Malloch, B. (Eds.), Wildl. Furbearer Management and Conservation in North America. Ontario Ministry of Natural Resources, Toronto, pp. 672-681.

Trani, M.K., Brooks, R.T., Schmidt, T.L., Rudis, V.A., Gabbard, C.M., 2001. Patterns and trends of early-successional forests in the eastern United States. Wildl. Soc. Bull. 29, 413-424.

Wagner, D.L., Nelson, M.W., Schweitzer, D.F., 2003. Shrubland lepidoptera of Southern New England and southeastern New York: ecology, conservation, and management. For. Ecol. Manage. 185, 95-112. 